DOI: $10.17951 / \mathrm{m} \cdot 2019.4 .9-21$

\begin{tabular}{lcr}
\hline & ANNALES \\
& UNIVERSITATIS MARIAE CURIE-SKŁODOWSKA & \\
LUBLIN - POLONIA & \\
VOL. IV & SECTIO M & 2019 \\
\hline
\end{tabular}

\author{
Beata Varga \\ University of Szeged Hungary \\ varga.bea@hist.u-szeged.hu \\ ORCID ID: http://orcid.org/0000-0001-7244-0783
}

\title{
From Autonomy to Independence - Attempts for the Establishment of Ukrainian Statehood
}

Thus far, attempts aimed at establishing a unified and independent Ukrainian state have failed to stand the test of time. This can primarily be explained with the "unequal" development of Ukraine, observed from a cultural-historical aspect. ${ }^{1}$ As regards contemporary Ukranian historiography ${ }^{2}$ and political authorities, present day Ukraine is considered to be the direct successor of the 17th century "Cossack state"s and the 1917-20 Ukrainian People's Republic. Having Bohdan Khmelnytsky put at the centre stage as the "Father of the Nation" and promoting Mykhailo Hrushevsky as first president of Ukraine, this "glorious history" has been employed for the creation of historical identity.

1 T. Krausz, Harc Ukrajnáért. Eszmélet 102. 2014. p. 32

2 V. Smolij, V., Stepankov, Ukrayins 'ka derzhavna ideya XVII-XVIII stolit'. Problemy' formuvannya, evolyuciyi, realizaciyi. Al’ ternaty`vy', Ky`yiv 1997. pp. 101-102.;V. M. Gorobecz', Vid soyuzu do y'nkorporacy 'y': ukrayinsko-rosijs 'ky' vidnosy 'ny' drugoyi polovy 'ny' XVII pershoyi chverti XVIII. st. Y`nsty`tut Y`storiyi Ukrayiny` NAN Ukrayiny`, Kiyiv 1995. p. 13.; Kry' kun, M., Mizh vijnoyu i radoyu. Kozacztvo pravoberezhnoj Ukrayiny 'v drugij polovy 'ni XVIIna pochatku XVIII stolittya. Kry'ty'ka, Kiyiv 2006. p. 13.; O. Shherbak, Ukrayins 'ke kozacztvo: formuvannya social 'nogo stanu. Druga polovy 'na XV - seredy'na XVIIst. KM Akademiya, Kiyiv 2006. pp. 251-252.; V. P. Shevchuk, M. G. Taranenko, Istoriya ukrayins 'koyi derzhavnosty'. Ly`bid’, Kiyiv 1999. p. 89.

3 P. R. Magocsi, A History of Ukraine - The Land and Its Peoples. University of Toronto Press, Toronto 2010. p. 209. 


\section{The "Cossack state"}

A former Ukrainian President, in a speech to the nation, stated that "the outstanding pioneers of Ukraine... with Bohdan Khmelnytsky in its ranks as a titanic figure... laid the foundation of the contemporary Ukrainian political nation.... Herein, he reached back to the Hetman as being the source of continuity of Ukrainian statehood ${ }^{5}$. The middle of the 17 th century is referred to by Ukrainian historiography as the "real Rubicon", which Ukrainians had to cross to make their decisive step towards their way to independence. ${ }^{5}$ Led by Bohdan Khmelnytsky, the "all-Ukrainian" movement of 1648-54 created a historical opportunity to realise the formation of a sovereign Ukraine for the first time. ${ }^{6}$ As for their major achievement, it is unequivocally the 1649 Treaty of Zboriv, ${ }^{7}$ which declared the so-called "Cossack Ukraine", including the Kiev, Bratslav and Chernihiv Viovodeships, to be autonomous. As a consequence, the establishment of the Hetmanite administrative organisation could evolve, thus representing the seeds of a sovereign Ukrainian state. Following the initial successes of the Ukrainian movement, Bohdan Khmelnytsky put the emphasis on the divine origin of the Hetman's power at the forefront. ${ }^{9}$ At the beginning of 1649, he took on a new function, described as "...Bohdan Khmelnytsky, Hetman of the Zaporizhian Host by God's Mercy..." ${ }^{\prime \prime}$. Moreover, claiming the divine origin of his power, he aimed at emphasizing the legitimate and sovereign nature of his power, and, at the same time, building the very foundations of his endeavour to introduce the hereditary Hetman title. ${ }^{11}$ Pursuing a polyvassalic policy and

4 V. Szereda, Történelmi emlékezet Ukrajna elnökeinek hivatalos beszédeiben. Regio (Kisebbség, Politika, Társadalom) 3. 2007. pp. 47-68.

5 T. Chuxlib, Kozakiy ' monarxi-Mizhnarodni vidnosy 'ny ' rann 'omodernoyi Ukrayins 'koyi derzhavy' 1648-1721 rr. , Vy`davny`czstvy` imeni Oleny` Teligy', Kiyiv 2009. p. 53.

6 V. Smolij, V., Stepankov, Ukrayins 'ka derzhavna ideya XVII-XVIII stolit'. Problemy' formuvannya, evolyuciyi, realizaciyi. Al'ternaty'vy', Ky`yiv 1997. p. 48.

7 Vossoedinenie Ukrainy s Rossiey. Dokumenty i materialy v 3 tomakh. Izdatelstvo Akademii Nauk SSSR, Moskva. 1954. Tom 1.1620-1647 gg.. pp. 299-306.

8 V. Smolij, V., Stepankov, Ukrayins 'ky 'j poly 'ty 'chny'j proekt XVII st.: stanovlennya naciy'onal'nogo y'nsty'tutu vlady'. Y’nsty`tut y`storiyi Ukrayiny` NAN Ukrayiny`, Kiyiv 2014. p. 24.

9 S. Ploxij, Bozhestvennoe pravo get`maniv: Bogdan Xmel`ny`cz`ky`j i problema legity`maciyi get`mans`ko valdy` v Ukraiyiny`. In: Mediaevalia ucrainica : mental 'nost' ta istoriya idej. III. Kiyiv 1994. pp.125-126.

${ }^{10}$ Arkhiv Yugo-Zapadnoy Rossii, izdavaemyy Vremennoyu komissieyu dlya razbora drevnikh aktov. (Arkhiv YuZR) Kiev1863, T. XIII. pp. 252-257.

11 A. Zyakun, «Monarxy`zm» B. Xmel`ny`cz kogo: gy`potezi ta realiyi. In: SvitoglyadFilosofiya-Religiya. zb. nauk. pracz'. 7. Sumy ': DVNZ „UABS NBU”. 2014. p. 103. 
also changing his "landlords" 12 of his own free will, the Cossack leader managed to accomplish a virtual independence that enabled the Ukranian state to exist practically without any legal declaration..$^{13}$ After the 1654. Treaty of Pereyaslav that resulted in Ukraine's voluntary accession to Russia, Khmelnytsky, although seeing less and less chance of it, continued to be engaged in the establishment of a lasting Ukrainian statehood and its legitimacy.

The Zaporizhian Host became the official denomination of the autonomous Hetmanate formed from Ukrainian territories - by then under Russian authority. This was organised on a military basis ${ }^{14}$ and governed by the freely-elected Hetman. The formula stood for both the Cossack army of 60.000 men at the Tsar's service and for the state organization.

It should be noted that contemporary Ukrainian historiography ${ }^{15}$ argues that the notion of Russian and Soviet historiography of Ukraine becoming subordinated to Russia after their "reunion" is unfounded. While appreciating the Hetman's political activity, they highlighted that between 1654 and $1657 \mathrm{Khmel-}$ nytsky succeeded in uniting all "ethno-Ukrainian" territories into an independent Ukrainian state, and, albeit he considered himself to be a vassal of the Russian Tsar, ${ }^{16}$ he exercised a sovereign governance ${ }^{17}$ throughout his rule, the major proof of which being the maintenance of entirely independent diplomatic relations.

12 O. Subtelny, Ukraine - A History 2000: University of Toronto Press, Toronto 2000. pp. 133-134.

${ }^{13}$ V. Smolij, V., Stepankov,Ukrayins 'ky ${ }^{j}$ poly ${ }^{\prime}{ }^{\prime}{ }^{\prime} c h n y ' j$ proekt XVII st.: stanovlennya naciy'onal 'nogo y 'nsty 'tutu vlady'. Y'nsty' tut y'storiyi Ukrayiny' NAN Ukrayiny', Kiyiv 2014. p. 185.; T. Chuxlib, Kozakiy ' monarxi-Mizhnarodni vidnosy 'ny' rann 'omodernoyi Ukrayins 'koyi derzhavy '1648-1721 rr. , Vy`davny`czstvy` imeni Oleny` Teligy`, Kiyiv 2009. pp. 54-55.

14 G. Papaky'n, Istoriya derzhavny'x ustanov Ukrayiny': Uryaduyuchy' insty 'tuciyi ta derzhavni ustanovy 'IX - pochatku XX. st. Y'nsty 'tut y 'storiyi Ukrayiny'. NAN Ukrayiny', Kiyiv 2010. p. 102.

${ }_{15}$ V. M. Gorobecz', Vid soyuzu do y'nkorporacy'y': ukrayinsko-rosijs 'ky' vidnosy 'ny' drugoyi polovy 'ny' XVII - pershoyi chverti XVIII. st. Y`nsty`tut Y`storiyi Ukrayiny` NAN Ukrayiny`, Kiyiv 1995. pp. 4-20; M. Kry`kun, Mizh vijnoyu i radoyu. Kozacztvo pravoberezhnoj Ukrayiny' v drugij polovy 'ni XVII- na pochatkuXVIII stolittya. Kry`ty`ka, Kiyiv 2006. p. 13.; O. Shherbak, Ukrayins 'ke kozacztvo: formuvannya social 'nogo stanu. Druga polovy'na XV seredy'na XVIIst. KM Akademiya, Kiyiv 2006. 251-252.

${ }_{16}$ T. Chuxlib, Kozakiy ' monarxi-Mizhnarodni vidnosy 'ny ' rann 'omodernoyi Ukrayins 'koyi derzhavy`1648-1721 rr. , Vy`davny`czstvy` imeni Oleny` Teligy`, Kiyiv 2009. p. 81.

17 V. Smolij, V. Stepankov, Ukrayins 'ky'j poly'ty chny`j proekt XVII st.: stanovlennya naciy 'onal 'nogo y'nsty 'tutu vlady'. Y`nsty` tut y`storiyi Ukrayiny` NAN Ukrayiny`, Kiyiv 2014. p. 188. 
It is beyond doubt that the Treaty of Pereyaslav is to be regarded as a crucial milestone in the formation of Ukrainian statehood, ${ }^{18}$ however, the process of building a state was significantly slowed down by the fact that Ukraine found itself stuck between the grip of three neighbouring countries, namely Rzeczpospolita, Russia and the Ottoman Empire. On the whole, with minor restrictions, however, Russian-Ukrainian relations formed as a result of the Treaty of Pereyaslav can be evaluated as a feudal relation relying on a wide autonomy. Theoretically, the Russian monarch preserved his authority over the Zaporizhian Host, yet he had been unable to exercise his legal supremacy during the rule of Bohdan Khmelnytsky in Ukraine, meaning that he had not had direct power in the Hetmanite, therefore, between 1654 and 1657 Ukraine possessed a so-called "virtual independence" ${ }^{\prime 19}$. When scrutinising Bohdan Khmelnytsky's diplomatic activity between 1648 and 1657, one can sum up that his foreign policy is to be considered as multivectorial, by means of which he intended to strengthen the Zaporizhian Host as a fully-fledged agent in international relations. ${ }^{20}$ Due to the effective employment of polyvassalic policy, the geopolitical position of Ukraine as a principally independent state was cemented until 1657, and the country was only nominally dependent on some monarchs of the region. ${ }^{21}$ Nevertheless, we must agree with the notion of not considering the Hetmanate, formed as a result of the Khmelnytsky-movement, a fully-fledged state. still, it has become the model of Ukrainian statehood for posterity. ${ }^{22}$

\section{The Ukrainian People's Republic}

Dissolution of the Russian and the Austro-Hungarian Empires provided a realistic opportunity for the solution of the "Ukrainian issue", that is the estab-

${ }_{18}$ Istoriya russko-ukrainskikh otnosheniy v XVII-XVIII vekakh. K 350-letiyu Pereyaslavkoy Rady. Institut rossiyskoy istorii RAN, Moskva 2006. p. 4.

19 S. Gebei, Stepen nezavisimosti Ukrainskogo getmanstva (seredina XVII veka). In: Moskoviya: spetsifika razvitiya- - Muscovy: The Peculiarities of its Development. Magyar Ruszisztikai Intézet, Budapest 2003. p. 194.

${ }^{20}$ T. Chuxlib, Kozaki y ' monarxi-Mizhnarodni vidnosy 'ny ' rann 'omodernoyi Ukrayins 'koyi derzhavy' 1648-1721 rr. , Vy`davny`czstvy` imeni Oleny` Teligy', Kiyiv 2009. p. 164.

${ }^{21}$ G. Papaky'n,.,Istoriya derzhavny'x ustanov Ukrayiny': Uryaduyuchy' insty 'tuciyi ta derzhavni ustanovy' IX - pochatku XX. st. Y'nsty 'tut y 'storiyi Ukrayiny'. NAN Ukrayiny', Kiyiv 2010. p. 102.

${ }^{22}$ Sz. Jekelcsik, Ukrajna története-Egy modern nemzet születése. Kairosz Kiadó, Budapest 2014. p. 50. 
lishment of a sovereign Ukrainian state including Eastern and Western Ukraine alike. $^{23}$

News on collapse of the Tsar's authoritarian regime reached Kiev on 3rd March, 1917, where the Centralnaja Rada (Central Rada, headed by Mykhailo Hrushevskyi, was founded by liberal and socialdemocratic leaders. They subsequently committed themselves to Ukraine's autonomy within Russia tranformed on federal bases, as declared in its I. Universal ${ }^{24}$ issued on 23rd June, 1917. Following the overthrow of the Provisional Government in October 1917, fighting for the acquisition of power began on the territory of Ukraine between supporters of the Provisional Government, the bolsheviks and the Centralnaja Rada ${ }^{25}$, resulting the latter emerging victorious and announcing in its III. Universal ${ }^{26}$ the establishement of the Ukrainian People's Republic. With regard to the fact that international agreement can only be signed by sovereign states, the Rada proclaimed independence of the Ukrainian People's Republic in the IV. Universal ${ }^{27}$ on 22nd January, 1918, however, at the same time it accepted the necessity of preservation of a unity with the Russian Federation to be formed. Nevertheless, they emphasised that their radical measures, as compared with their original plans, were a consequence of being forced by external circumstances. ${ }^{28}$ Therefore, under the direction of Hrushevskyi, the Centralnaja Rada walked the path from gaining autonomy to achieving independence, ${ }^{29}$ yet one must emphasize the fact that initially the idea of Ukraine breaking away from Russia had not been considered due to the fact that with Ukraine lacking separate statehood in 1917,

${ }^{23}$ G. Papaky`n, Istoriya derzhavny'x ustanov Ukrayiny': Uryaduyuchy' insty 'tuciyi ta derzhavni ustanovy 'IX - pochatku XX. st. Y'nsty 'tut y 'storiyi Ukrayiny'. NAN Ukrayiny', Kiyiv 2010. p. 237

${ }^{24}$ Ukrayins `ka Central’na rada: Dokumenty` i materialy` u 2 tomax. (UCzR) Naukova dumka, Kiyiv 1997. T 1. pp. 102-105.

${ }^{25}$ P. R. Magocsi, A History of Ukraine - The Land and Its Peoples. University of Toronto Press, Toronto 2010. p. 511.

${ }^{26}$ Ukrayins `ka Central`na rada: Dokumenty` i materialy` u 2 tomax. (UCzR) Naukova dumka, Kiyiv 1997.T. 1. pp. 398-401.

27 Ukrayins`ka Central`na rada: Dokumenty` i materialy` u 2 tomax. (UCzR) Naukova dumka, Kiyiv 1997. T. 2. pp. 102-104.

${ }^{28}$ Y. Y. Daczkiv, Dy`plomaty` Ukrayins`koyi Central`noyi Rady`u proty`stoyanni z bil`shovy`cz 'ky`my` delegaciyamy` Petrograda i Xarkova na Brests`kij my`rnij konferenciyi. In: Gileya-Naukovy`j visny`k, Kiyiv 2009. p. 47.

${ }^{29}$ Daczkiv, Y`. B., Dy`plomaty` Ukrayins`koyi Central noyi Rady`u proty`stoyanni z bil`shovy`cz 'ky`my` delegaciyamy` Petrograda i Xarkova na Brests`kij my`rnij konferenciyi. In: Gileya-Naukovy'j visny 'k, Kiyiv 2009. p. 15.; Rumyancev, V. - Straxov, E., Pravo v pery'od ukray'nskoj revolyucy 'y'. Pravo Ukray`ni.. 1. 2013. p. 283. 
the reality of e federation involving Russian and other nations definitely received greater support. ${ }^{30}$

Irrespectively of the Red Army's invasion of the left bank Ukrainian territories in January 1918, during the Brest-Litovsk negotiations, the Rada signed a separate peace agreement ${ }^{31}$ with the Central Powers. Thi, resulted ig that Germany and its allies acknowledged the Ukrainian People's Republic as an independent state and made a vow to liberate Ukraine from bolshevik rule. In return, the Ukrainian People's Republic undertook to ship agricultural products to Germany and the Austro-Hungarian Empire. Subsequently, after signing the Treaty of Brest-Litovsk, Soviet Russia engaged itself to sign a peace treaty with the Ukrainian People's Republic, recognisd its status as a natioe, withdraw troops from its territories and state that it would not interfere in its domestic affairs. ${ }^{32}$ The German government had an interest in seeing smaller sovereign states being born in the Eastern-European region which could have the ability to counterweight Russia's power and then gradually become part of Germany's economic sphere of interest. Obviously, this might explain wht German leaders supported the creation of an independent Ukrainian statehood in 1918. Furthermorr, by signing e separate peace agreement, Ukraine had taken s crucial step in its foreign policy, due to which the Ukrainian state had become elevated to an international level. ${ }^{33}$

On 2nd March, 1918, 45.000 troops of the Imperial German and AustroHungarian armies marched in Kiev and restored the power of the Centralnaja Rada, yet its position remained uncertain, since in order to secure independence they had to emplod foreign troops. Eventually, efforts to form a firm state apparatus failed, in addition, German demands had not been met, either.

\section{The Hetmanate - Ukrainian State}

The German management dissolved the Rada on 29th April, 1918, terminating the Ukrainian People's Republic and creating the Hetmanate led by Pavlo

\footnotetext{
30 S. Gebei, Az ukrán kérdés a nemzetközi béketárgyalásokon (1918-1921). Acta Acad. Agriensis, Sectio Historiae (XLIII.) 2015. p. 73.

${ }^{31}$ Ukrayina u mizhnarodny 'x vidnosy 'nax XX. stolittya. Pod red. V Mel`ny`ka Uzhgorod, 1999. http://library.if.ua/book/10/1031.html

${ }^{32}$ Khrestomatiya po otechestvennoy istorii (1914-1945). (Khrestomatiya) Gumanitarnyy izdatelskiy tsentr VLADOS, Moskva 1996. pp. 640-642.

${ }^{33}$ D. B. Daczkiv, Dy`plomaty` Ukrayins`koyi Central`noyi Rady` u proty`stoyanni z bil`shovy`cz 'ky`my` delegaciyamy` Petrograda i Xarkova na Brests`kij my`rnij konferenciyi. In: Gileya-Naukovy’j visny`k, Kiyiv 2009. p. 35.
} 
Skoropadsky, who proclaimed the establishment of e "Ukrainian State", that was the legitimate and legally continued successor of the Ukrainian People's Republic. The Hetmanate possessed the utmost legislative and executive power, ${ }^{34}$ it appointed the heads of the judiciar, and handled the army and foreign affairs. On top of these, it maintained permanent diplomatic relations with Germany, Switzerland, Turkey, Poland, Finland, Great Britain and France, which facilitated the international recognition of the Hetmanate. However, the Hetmanate governance symbolised the return of Russian imperial bureaucracy into power, which limited the long-term operability of the conservative state apparatus from the very outset. oollowing the collapse of the Western Front, German troops withdrew from Ukraine on 14th December, 1918, the Hetman left with them, too. Concerning the causes triggering the fall of the Hetmanate's fall, we must emphasize that Skoropadski's Ukrainian state created a military dictatorship in the form of a monarchy that was able to only rely on a really narrow social bass..$^{35}$ With the fall of the Hetmanate, the attempt to realise a Ukrainian state based on conservative notions failed, too.

\section{West Ukrainian People's Republic - is Galicia th "“Ukrainian Piemont”?36}

Following the first division of Poland, according to the Treaty of Saint Petersburg $^{37}$ signed on 5th August, 1772, the Habsburgs acquired the Kingdom of Galicia and Lodomeria (Galicia et Lodomeria), Auschwitz and the Duchy of Zator. ${ }^{38}$ Due to the reforms of Maria Theresa and Joseph II, life conditions in Galicia significantly improved, therefore, loyalty to the Habsburg dynasty deeply took root in Ukrainians. ${ }^{39}$ Indeed, whilecCurrent Austrian policies in Galicia did not always necessarily favour Ukrainian national aspirations, it provided them with more leeway than Tsarist Russia did. Owing to this, under Habsburg rule it was Ukrainian nationalism formed in Galicia thad kept Ukrainian identity alive and that turned out to be a crucial cradle of Ukrainian indentity. As regards

${ }^{34}$ V. Rumyancev, V. Straxov, Pravo v pery 'od ukray 'nskoj revolyucy'y`. Pravo Ukray`ni.. 1. 2013. p 290.

${ }_{35}$ O. Subtelny, Ukraine - A History 2000: University of Toronto Press, Toronto 2000. p. 359.

36 I. Vusko, The Politics of Cultural Retreat - Imperial Bureaucracy in Austrian Galicia, 1772-1867. Yale University Press, New Haven and London. 2015. p. 10.

37 F. F. Martens, Sobranie traktatov i konventsiy, zaklyuchennykh inostrannymi derzhavami. II. Traktaty s Avstriyeyu 1772-1818. Tipografiya Ministerstva Putey Soobshcheniya, Sanktpetersburg 1875. p. 15.

${ }^{38}$ É. Ring, Lengyelországot az anarchia tartja fenn? ELTE Eötvös Kiadó, Budapest 2001. p. 244.

${ }^{39}$ J-P. Himka, Confessional Relations in Galicia. In: A Multicultured Land, edited by Chriss Hann and Paul Robert Magocsi. University of Toronto Press, Toronto. 2005. pp. 27-28. 
its political aspirations, Ruthenian leadership was not unified, nevertheless, all political groups and trends acknowledged thae political independence was the only guaranted re the socio-economic and cultural development of Ukrainian territories under the then control of the Austrian and Russian Empires.

On 14th October, 1914, Ukrainians of Galicia established the General Ukrainian Rada, aon expressed thets loyalty to the Habsburg dynasty ${ }^{40}$ in a declaration hoping that a Habsburg victory coupled with a Romanov defeat may soon bring freedom to Ukrainians. ${ }^{41}$ In additioo, a group emigrated from Russia-ruled Ukraine founded its own organisation in Lembered the Union for the Liberation of Ukraine, ${ }^{42}$ aiming to accomplish the independence of Ukraine frin Russia, and the autonomy of East-Galicia. the formation of the West Ukrainian People's Republic was announced in Lemberg in 1918. Here, tch state form needed much less time to assume legislatiin order and to set up an operable and effective administrative apparatus than it would have in East-Ukraine, the reason being that Western-Ukrainian society was much less divided, thus it enabled them to join hands in the struggle against the Poles.

\section{Directorate of Ukraine}

Following the downfall of the Hetmanate, the Directorate of Ukraine invaded Kiev and restituted the Ukrainian People's Republic. With a fast-paced statebuilding based on a republican form of government as their chief objective, still, similarly to the Hetmanate, they were unable to shape a solid internal social base and settle external relations with Soviet Russia, the Entente Powers ${ }^{43}$ and Poland, which countries had no interest in seeingan Ukrainian state exist.

TheuUnion of the Ukrainian People's Republic and the West Ukrainian People's Republic, their capitals being Kiev and Lemberg, respectively, took place during the period of the Directorate on 22 January, 1919. ${ }^{44}$ However, the merger of the Ukrainian territories remained to be only on the level of declaration, sincr

${ }^{40}$ Sz. Jekelcsik, Ukrajna története-Egy modern nemzet születése. Kairosz Kiadó, Budapest 2014. p. 90.

${ }_{41}$ O. Subtelny, Ukraine - A History 2000: University of Toronto Press, Toronto 2000. p. 340.

42 O. Supronyuk, Chasopy`s «Vy`sny`k soyuzu vy`zvolennya Ukrayiny`» (vy`den`, 19141918) yak chy`nny`k stanovlennya derzhavnosty` Ukrayiny`.In: Seriya y 'story 'chni nauky ' 23. 2015. p. 63.

${ }_{43}$ Ya. V., Ponenko, Dy 'plomaty'chni vzaэmy 'ny' Ukray 'ns 'koyi Narodnoyi Respubliky' $z$ krayinamy' Antanty' za doby' Dy'rektoriyi (1918-1921 rr.). aftoref dy 's. .kand. y'st. nauk. Zaporizhzhya 2006. p. 20.

44 Akt Zluky` spy`ravsya na spokonvichnu mriyu ukrayinciv. https://borinfo.com.ua/ boryspil-products-news-2012-01-308-4/ 
harsh military conditions thwarted their actual uniting. Moreover, this union could not be a long-lived one, either, due to the fact thathe well-organised state apparatus made up of Western-Ukrainian moderate nationalist wen unable to cooperate withe Directorate conducting a policy of left-wing sympathies. Apart from this, neither were Western Ukrainians willing to make a compromise with the Poles, whereas their eastern counterparts perceived the Polish as the one and only ally against Soviet Russia. ${ }^{45}$

Considering that their endeavours for the creation of a independent Ukrainian state proved to be unsuccessful with either German or French support, ${ }^{46}$ Ukrainians, therefore, initiated peace talks with the Polish government. Following the capitulation of Germany and the Austro-Hungarian Empire, the Entente Powers were in favour of Poland's aspiration for the establishment of a state, since a strong Polish state had the potential to contain a possible German or Soviet-Russian expansion. This tendency was incompatible with the notion of a sovereign, independent Ukraine. Although the majority of Polish political leaders still regarded Ukrainians to be too ieapt to sng up a worki a sovereign Ukrainian state, yet Pilsudski was still thinking of a federate formed from Poland, Lithuania, Ukraine and Belorussia, one being able to counter Soviet Russia. ${ }^{47}$ In accordance with the Polish-Ukrainian Agreement concluded on 21st April, 1920, Poland recognised the well-founded and legitimate expansive aspirations of the Ukrainian People's Republic on Soviet Russia in the eastern region, up to the first border of the Rzeczpospolita prior to the first territorial division, that is the river Dnieper. Subsequently, they launched a joint attack against Soviet Russia on 25 April, 1920, the apex of which war being the battle of Warsaw on 13-25 August, where the Red Army wa eventually held up.

The Polish parliament then did not support continuation of the war for Ukrainian interests, and ceasefire talks were initiated with Moscow. Soviet Russia and Poland signed the Treaty of Riga ${ }^{48}$ in March, 1921, which once and for all terminated Ukrainian endeavours for becoming independent, thus providing the recurrence of the situation that emerged in the wake of the 1667 Truce of

${ }^{45}$ Sz. Jekelcsik,Ukrajna története-Egy modern nemzet születése. Kairosz Kiadó, Budapest 2014. p. 104.

${ }^{46}$ Y. Daczkiv, Dy 'plomatiya ukrayins 'ky'x nacional 'ny'x uryadiv u zaxy 'sti derzhavnosti (1917-1923 rr). AFTOREFERAT dy`sertaciyi na zdobuttya stupenya doktora istory`chny`x nauk Kiyiv 2010. p. 22.

${ }^{47}$ S. Gebei, Az ukrán kérdés a nemzetközi béketárgyalásokon (1918-1921). Acta Acad. Agriensis, Sectio Historiae (XLIII.) 2015. p. 83.

${ }^{48}$ D. Halmosy, Nemzetközi szerződések 1918-1945. Közgazdasági és Jogi KönyvkiadóGondolat Könyvkiadó, Budapest 1983. pp. 173-178. 
Andrusovo, ${ }^{49}$ as Poles and Russians, disregarding Ukrainian interests, divided Ukraine between them.

Between 1917-1920, Ukrainians established a temporary sovereign state, nevertheless, consecutive governments were in power for only short periods, therefore they could n't cement their rule. Yet a further factor in aggravating the achievement of independence was that the Ukrainis' national identity reached a lower level as compared to Galicia. Nevertheless, the main problem resulted from the lack of a common standpoint in certain Ukrainian regions and the political parties regarding the nature of the Ukrainian state. Apart from creating an autonomous state withinhe democratic Russia, one could observe a failed attempt for the establishment of a conservative monarchy, a nationalist military dictatorship ${ }^{50}$ and an independent republic. On top of all this, the military overpower of Poland and Soviet Russia as well as the indifference of the victorious (in WWI) Entente Powers regarding the existence of a sovereign Ukraine contributed to the above. Ultimately, similar to the 17th and 18th centuries, development of the Ukrainian nation again took place from 1921 within the boundaries of two states, namely within the Soviet Union, and in the reborn Poland.

\section{Summary}

Primarily, the absence of an inherited national identity contributed to the dividedness of Ukraine, and its lengthy processes of nation and state building, therefore, certain territories proved to more "mature", while others ended up as "undeveloped". In the course of the long historical process from autonomy to the birth of the independent Ukrainian state, Ukrainian territories had become the double, then triple periphery of power spheres. Starting from the second half of the 17th century, Bohdan Khmelnytsky's "Cossack state" got into the grip of Hetmans representing various political orientation and the neighbouring powers. In additier, by the end of the First World War, Ukraine had become the battlefield of combating Ukrainian leaders, and the Central and Entente Powers. Nevertheless, a similarity was apparent in both historical situations in the sense that not only the unfavourable political environment, but internal dividedness stood as an obstacle to the creation of unity and

\footnotetext{
${ }^{49}$ Akty, otnosyashchiesya $\mathrm{k}$ istorii Yuzhnoy i Zapadnoy Rossii, sobrannye i izdannye Arkheograficheskoy komissiey. (Akty YuZR) Sanktpetersburg 1869. T. VI. pp. 173-176.

${ }^{50}$ N. D. Sorokina, Konflikt na Yuge-vostoke Ukrainy: istoriya povtoryaetsya? In:Teorii i problemy politicheskikh issledovaniy. 4. 2016. p. 126.
} 
self-sufficiency. In the time of the 17th and 20th century "Ukrainian revolution", it was n't in any of the region's significant powe's' interest to give rise to a sovereign Ukrainian state. consequently, in both cases, a sovereign Ukraine actually wan a "historical dead end".

\section{Bibliography}

\section{Sources}

- Akty, otnosyashchiesya k istorii Yuzhnoy i Zapadnoy Rossii, sobrannye i izdannye Arkheograficheskoy komissiey. (Akty YuZR) 1869: VI. T. Sanktpetersburg 1869.

- Akt Zluky`spy`ravsya na spokonvichnu mriyu ukrayinciv. https://borinfo.com.ua/ boryspil-products-news-2012-01-308-4

- Arkhiv Yugo-Zapadnoy Rossii, izdavaemyy Vremennoyu komissieyu dlya razbora drevnikh aktov. (Arkhiv YuZR) Kiev1863, T. XIII.

- Khrestomatiya po otechestvennoy istorii (1914-1945). (Khrestomatiya) Gumanitarnyy izdatelskiy tsentr VLADOS, Moskva 1996.

- Martens F. F. 1875: Sobranie traktatov i konventsiy, zaklyuchennykh inostrannymi derzhavami. II. Traktaty s Avstriyeyu 1772-1818. Tipografiya Ministerstva Putey Soobshcheniya, Sanktpetersburg 1875.

- Ukrayins `ka Central`na rada: Dokumenty` i materialy` u 2 tomax. (UCzR) Naukova dumka, Kiyiv 1997

- Vossoedinenie Ukrainy s Rossiey. Dokumenty i materialy v 3 tomakh. Izdatelstvo Akademii Nauk SSSR, 1954:, Moskva. Tom 1. 1620-1647 gody, Tom 2. 1648-1651 T. 3. 1651-1654 gg.

\section{Literature}

- Chuxlib T., Kozaki y' monarxi- Mizhnarodni vidnosy'ny' rann 'omodernoyi Ukrayins 'koyi derzhavy' 1648-1721 rr. , Vy`davny`czstvy` imeni Oleny` Teligy`, Kiyiv 2009.

- Daczkiv Y`. B., Dy`plomaty` Ukrayins`koyi Central`noyi Rady`u proty`stoyanni z bil`shovy`cz`ky`my` delegaciyamy` Petrograda i Xarkova na Brests`kij my`rnij konferenciyi. In: Gileya-Naukovy 'j visny'k, Kiyiv 2009. pp. 31-49.

- Daczkiv Y., Dy 'plomatiya ukrayins 'ky'x nacional 'ny 'x uryadiv u zaxy'sti derzhavnos$t i(1917-1923 \mathrm{rr}$ ). AFTOREFERAT dy`sertaciyi na zdobuttya stupenya doktora istory`chny`x nauk Kiyiv 2010.

- Fedinec Cs., Halász I.-Tóth M., A független Ukrajna - államépités, alkotmányozás és elsüllyesztett kincsek. MTA Társadalomtudományi Kutatóközpont Kalligram, Budapest 2016.

- Gebei S., Stepen nezavisimosti Ukrainskogo getmanstva (seredina XVII veka). In: Moskoviya: spetsifika razvitiya- - Muscovy: The Peculiarities of its Development. Magyar Ruszisztikai Intézet, Budapest 2003. pp. 183-194.

- Gebei S., Az ukrán kérdés a nemzetközi béketárgyalásokon (1918-1921). Acta Acad. Agriensis, Sectio Historiae (XLIII.) 2015. pp. 71-101. 
- Gorobecz' V. M., Vid soyuzu do y'nkorporacy 'y': ukrayinsko-rosijs 'ky 'vidnosy 'ny' drugoyi polovy 'ny' XVII - pershoyi chverti XVIII. st. Y'nsty` tut Y'storiyi Ukrayiny' NAN Ukrayiny', Kiyiv 1995.

- Halmosy D., Nemzetközi szerződések 1918-1945. Közgazdasági és Jogi KönyvkiadóGondolat Könyvkiadó, Budapest 1983.

- Himka J.-P., Confessional Relations in Galicia. In: A Multicultured Land, edited by Chriss Hann and Paul Robert Magocsi. University of Toronto Press, Toronto. 2005. pp. 22.35.

- Istoriya russko-ukrainskikh otnosheniy v XVII-XVIII vekakh. K 350-letiyu Pereyaslavkoy Rady. Institut rossiyskoy istorii RAN, Moskva 2006.

- Jekelcsik Sz., Ukrajna története-Egy modern nemzet születése. Kairosz Kiadó, Budapest 2014.

- Karácsonyi D., A kelet-európai sztyep és a magyar Alföld mint frontier-területek. Földrajzi értesitó LVII. 1-2. 2008. pp. 185-211.

- Krausz T., Harc Ukrajnáért. Eszmélet 102. 2014. pp.28-33.

- Kry'kun M., Mizh vijnoyu i radoyu. Kozacztvo pravoberezhnoj Ukrayiny' $v$ drugij polovy 'ni XVII-na pochatkuXVIII stolittya. Kry`ty'ka, Kiyiv 2006.

- Magocsi P. R., A History of Ukraine - The Land and Its Peoples. University of Toronto Press, Toronto 2010.

- -Magocsi P. R., The Roots of Ukrainian Nationalism. Galícia as Ukraine's Piedmont. University Press of Toronto, Toronto 2002.

- Papaky'n G., Istoriya derzhavny'x ustanov Ukrayiny': Uryaduyuchy' insty 'tuciyi ta derzhavni ustanovy' IX - pochatku XX. st. Y'nsty'tut y'storiyi Ukrayiny'. NAN Ukrayiny', Kiyiv 2010.

- Ploxij S., Bozhestvennoe pravo get`maniv: Bogdan Xmel`ny`cz`ky`j i problema legity`maciyi get mans`ko valdy`v Ukraiyiny`. In: Mediaevalia ucrainica : mental'nost' ta istoriya idej. III. Kiyiv 1994.

- Ponenko Ya. V., Dy 'plomaty 'chni vzaэmy 'ny' Ukray 'ns 'koyi Narodnoyi Respubliky' $z$ krayinamy 'Antanty 'za doby' Dy 'rektoriyi (1918-1921 rr.). aftoref dy 's. .kand. y 'st. nauk. Zaporizhzhya. 2006.

- Ring É., Lengyelországot az anarchia tartja fenn? ELTE Eötvös Kiadó, Budapest 2001.

- Rumyancev V. - Straxov, E., Pravo v pery 'od ukray 'nskoj revolyucy 'y'. Pravo Ukray'ni.. 1. 2013. pp. 282-300.

- Shherbak O., Ukrayins 'ke kozacztvo:formuvannya social'nogo stanu. Druga polovy 'na $X V$ - seredy'na XVIIst. KM Akademiya, Kiyiv 2006.

- Shevchuk V. P., Taranenko, M. G., Istoriya ukrayins 'koyi derzhavnosty'. Ly' bid', Kiyiv 1999.

- Sirka A., 1980: The Nationality Question in Austrian Education - The Case of Ukrainians Galicia 1867-1917. Frankfurt am Main: European University Studies. 1980 pp. $1-33$.

- Smolij V., Stepankov, V., Ukrayins 'ka derzhavna ideya XVII-XVIII stolit'. Problemy' formuvannya, evolyuciyi, realizaciyi. Al 'ternaty'vy', Ky'yiv 1997.

- Smolij V., Stepankov, V., Ukrayins 'ky 'j poly'ty 'chny 'j proekt XVII st.: stanovlennya naciy'onal'nogo y 'nsty 'tutu vlady'. Y'nsty'tut y' storiyi Ukrayiny' NAN Ukrayiny', Kiyiv 2014. 
- Sorokina N. D., Konflikt na Yuge-vostoke Ukrainy: istoriya povtoryaetsya? In:Teorii i problemy politicheskikh issledovaniy. 4. 2016. pp. 119-134.

- Subtelny O., Ukraine - A History 2000: University of Toronto Press, Toronto 2000.

- Supronyuk O., Chasopy`s «Vy`sny`k soyuzu vy`zvolennya Ukrayiny`» (vy`den`, 19141918) yak chy`nny`k stanovlennya derzhavnosty`Ukrayiny`. In: Seriya y 'story 'chni nauky' 23. 2015. pp. 59-64.

- Szereda V., Történelmi emlékezet Ukrajna elnökeinek hivatalos beszédeiben. Regio (Kisebbség, Politika, Társadalom) 3. 2007. pp. 47-68.

- Ukrayina u mizhnarodny'x vidnosy 'nax XX. stolittya. Pod red. V Mel`ny`ka Uzhgorod, 1999. http://library.if.ua/book/10/1031.html

- Vusko I., The Politics of Cultural Retreat - Imperial Bureaucracy in Austrian Galicia, 1772-1867. Yale University Press, New Haven and London. 2015.

- Zyakun A., «Monarxy`zm» B. Xmel`ny`cz` kogo: gy`potezi ta realiyi. In: SvitoglyadFilosofiya-Religiya.zb. nauk. pracz`. 7. Sumy': DVNZ „UABS NBU”. 2014. pp. 94-104.

Summary: This text analyzes two attempts aimed at the establishment of a unified and independent Ukrainian state. As regards contemporary Ukranian historiography and political authorities, they consider present day Ukraine to be the direct successor of the 17th century "Cossack state" and the 1917-20 Ukrainian People's Republic. A similarity was apparent in both historical situations in the sense that beyond the unfavourable political environment, internal dividedness stood as an obstacle to the creation of unity and self-sufficiency.

Keywords: Ukrainian statehood, Treaty of Pereyaslav, Ukranian People's Republic, The Ukrainian Hetmanate, Directorate of Ukraine

\section{Od autonomii do niepodległości - próby ustanowienia ukraińskiej państwowości}

Streszczenie: Tym, co przyczyniło się do podziału Ukrainy i długotwałości procesów budowania narodu i państwa, był przede wszystkim brak dziedziczonej tożsamości narodowej, dlatego też niektóre jej terytoria okazały się bardziej „dojrzałe”, a inne „nierozwinięte”. W trakcie długiego procesu historycznego, biegnącego od autonomii do narodzin niezależnego państwa ukraińskiego, terytoria ukraińskie stały się podwójnym, a następnie potrójnym peryferiami sfer władzy. Począwszy od drugiej połowy XVII wieku, „państwo kozackie” Bohdana Chmielnickiego wpadało w ręce hetmanów reprezentujących różne orientacje polityczne i sąsiednie mocarstwa, co więcej, pod koniec pierwszej wojny światowej Ukraina stała się polem walki przywódców ukraińskich oraz mocarstw centralnych i ententy. W obydwu tych sytuacjach historycznych dają się dostrzec podobieństwa, polegające nie tylko na istnieniu niesprzyjającego środowiska politycznego, ale także i wewnętrznych podziałów stojących na drodze do jedności i samostanowienia. W czasach „rewolucji ukraińskich” z XVII i XX wieku powstanie suwerennego państwa ukraińskiego nie leżało w interesie żadnej z regionalnych potęg, w związku z czym w obu tych przypadkach Ukraina znalazła się w „historycznym ślepym zaułku”.

Słowa kluczowe: Państwowość Ukrainy, Ukraińska Republika Ludowa, Ukraiński Hetmanat, Dyrektoriat Ukrainy 